\title{
Vård och omsorg om förskolebarn i Sverige och England
}

\author{
ELINOR BRUNNBERG
}

Ett engelskt daghem i offentlig regi motsvaras av fyrtiosex svenska. Det är bara ett exempel på stora skillnader mellan Sveriges och Englands stöd till barnfamiljer. I England betraktas vård och omsorg om små barn som ett privat problem och en uppgift framför allt för kvinnorna medan det i Sverige också är ett offentligt ansvarsområde. Den svenska staten kan därför beskrivas som en tvåpartsvårdarstat medan den engelska snarare är en kvinnovairdarstat.

Den här artikeln är en jämförelse av hur vård och omsorg om förskolebarn är organiserad i Sverige och England. Det rör sig om två länder som båda har en lång tradition som välfärdssamhällen, men som ändå präglas av olika kulturer och till viss del av skilda socialpolitiska system. Fungerar omsorgen om de minsta barnen i de båda länderna också efter skilda socialpolitiska principer? Hur stort ansvar har familjen? Vilken syn har staten på mäns och kvinnors ansvar för vård och omsorg av små barn? Vilket ansvar

Elinor Brunnberg är doktorand i socialt arbete vid Universitetet i Göteborg och journalist. Hon är verksam vid Högskolan i Örebro. Där arbetar hon bl.a med en jämförande studie av socialt arbete i Sverige och England som bekostas av SFR. tar stat eller kommun i omsorgen om förskolebarnen?

De socialpolitiska systemen är mycket olika i skilda länder men också inom ett land kan olika delar av det socialpolitiska systemet bygga på olika modeller. Samtidigt händer det mycket inom det socialpolitiska området och indelningar som gjorts kan snabbt kännas föråldrade.

Gösta Esping-Andersen gör en indelning av välfärdsstaterna i tre kategorier: Social Democratic, Corporatist och Liberal på basis av hur de kan placeras efter ett decommodifikationsindex mätt när det gäller tillgänglighet för personer mellan 16-64 av sjukpenning, arbetslöshetsförsäkring och pensioner (Esping-Andersen 1990). Begrep- 
pet de-commodifikation beskriver i vilken utsträckning individer eller familjer kan upprätthålla en socialt acceptabel levnadsstandard oberoende av i vilken utsträckning de deltar på marknaden. Stödet till barnfamiljerna spelar ingen roll i Esping-Andersens index. Han karakteriserar Sverige som en stat med stark socialistisk prägel medan England framförallt har en liberal prägel även om där också finns inslag av socialism. Det som i England framförallt avviker från den liberala prägeln är sjukvården som i huvudsak har en generell karaktär. En stor europeisk undersökning (Bradshaw m.fl. 1993) av de stödpaket för barnfamiljer som förekommer i femton europeiska länder, dock inte Sverige, visade att om välfärdsstaterna också hade rangordnats på basis av stödet till barnfamiljerna hade Esping-Andersens kategoriseringar av länderna sett annorlunda ut. I den komparativa europeiska studien jämfördes både struktur och nivå på stödet till barnfamiljerna. Det bestod av socialförsäkringsbidrag, underhållsbidrag och andra arrangemang med särskilda bidrag till ensamstående föräldrar och liknande hjälp som t.ex. matchecker. Det inkluderade också olika skattearrangemang och bidrag som påverkar kostnader för bostad, sjukvård, skola och förskola.

Detta pekar mot att det inte är självklart att man med några få variabler kan fånga ett lands hela socialpolitiska system. Det kan finnas skäl att klassificera olika beroende på vilket socialpolitiskt fokus det gäller. De olika klassifikationssystemen tycks i huvudsak bygga på hur strukturen av olika bidragssystem är uppbyggda, men för ett område som vård och omsorg handlar det också om vilket ansvar det offentliga tar för den direkta omsorgen om t.ex. barnen i olika typer av barnomsorgsverksamheter. Genom organiseringen av omsorgen om de små barnen (Leira 1992) skapas förbindelselinjer mellan en emotionell, individuell och privat sfär och offentliga myndigheters ansvarsområde. Vilket ansvar de offentliga myndigheterna tar i det här sammanhangen har naturligtvis en mycket stor betydelse för de enskilda människornas välfärd och vardagsliv. Esping Andersen har kritiserats av kvinnoforskare för att han i sin analys inte diskuterar det obetalda arbetet. Jane Lewis (1992) menar att den viktiga skärningspunkten inte enbart finns mellan betalt arbete och välfärd utan mellan betalt arbete, obetalt arbete och välfärd. Lewis beskriver England som ett exempel på en stark "Malebreadwinner-stat" medan Sverige snarast karakteriseras som en "Dualbreadwinner-stat». I sin ideala form föreskriver "Malebreadwinner-modellen« att mannen står för försörjningen och kvinnan för vård och omsorg. I "Dualbreadwinner-modellen" delar man på ansvaret. Starka "malebreadwinner-länder w har tenderat att dra en skarp skiljelinje mellan offentliga och privata ansvarsområden, skriver Lewis. Kvinnorna i Sverige har knuffats ut på arbetsmarknaden i betalt arbete genom introducerandet av särbeskattning 1971 och föräldraledighet 1974 och en ökande barnomsorg, skriver Lewis. Detta ledde till att kvinnors arbetskraftsdeltagande ökade dramatiskt, men också till att kvinnors beroende av staten ökade.

En annan socialpolitisk kvinnoforskare, Anneli Anntonen (1990) menar att de skandinaviska staterna kan beskrivas som sociala servicestater eller omsorgsstater. I 
Sverige t.ex. tar staten en mycket aktiv del i vård och omsorg om barn, gamla, sjuka och handikappade. Utvecklingen av den moderna sociala servicestaten har fått konsekvensen att kvinnorna har lämnat det obetalda arbetet hemma och istället ägnar sig åt betalt arbete inom den offentliga sfären. Barnomsorgen och omsorgen om de äldre tas fortfarande till stor del hand om av kvinnorna men nu som betalt arbete.

Också Antonnen pekar på att utvecklandet av den moderna Skandinaviska servicestaten visserligen har inneburit att kvinnorna frigjorts från det ekonomiska beroendet av männen men istället blivit mer beroende av staten både för att få tillgång till barnomsorg för sina barn eller äldreomsorg för de gamla men också för sin ekonomiska försörjning.

En grundläggande tanke $\mathrm{i}$ feministisk teori är att staten inte är neutral $i$ intressemotsättningen mellan könen. Staten skapar ideologiska, ekonomiska och maktpolitiska förutsättningar för att män skall kunna upprätthålla sin överordning över kvinnor. Barn beskrivs ofta $\mathrm{i}$ termer av "den mänskliga reproduktionen" och objektifieras. Samtidigt befinner de sig mitt i det spänningsfält där könsmakten utövas och där positioner bestäms. Förändringarna i relationen mellan offentligt och privat, mellan stat och familj är ett centralt analysfält för kvinnoforskningen. Förändringarna i de skandinaviska välfärdsstaterna har bl.a. av Birte Siim och Anette Borchorst tolkats som ett uttryck för ett ömsesidigt förhållande mellan staten och familjen, som kan bidra till att omfördela ansvaret för den mänskliga reproduktionen från den privata familjesfären till den offentliga sfären. De går t.o.m. så långt att de beskriver relationen mellan kvinnorna och staten i de skandinaviska länderna som ett partnerskap, en allians som nödvändigtvis inte måste vara medveten, men som inneburit att kvinnorna t.ex. genom barnomsorgspolitiken fått nya medborgerliga rättigheter som minskat deras beroende av äktenskapskontraktet. Birte Siim skriver:

Kvinnors ökade beroende av staten som konsumenter på daghemsområdet, måste tolkas som en positiv utveckling, eftersom den har gett kvinnor större möjligheter att som lönearbetare, mödrar och medborgare förändra könsmaktsrelationer i det privata och det offentliga livet (Siim 1990:2:19).

Anette Borchorst (1992) menar att genom att de kvinnovänliga potentialerna inom den skandinaviska välfärdsstaten ökat och kvinnor fått en ökande ekonomisk självständighet så har patriarkatets intensitet minskat. Det är ändå långt till att jämställdhet råder och på vissa områden har patriarkatet bara ändrat form, menar hon. Den andra sidan av myntet är att kvinnor också blivit mer beroende av välfärdsstaten. Detta gör kvinnor särskilt sårbara i omstruktureringsprocesserna. Anette Borchorst menar nämligen att det i högre grad skett en förskjutning från det privata till det offentliga än en grundläggande påverkan av könsarbetsdelningen. Det i sin tur faller tillbaka på kvinnor om den offentliga omsorgen på nytt förs tillbaka till familjerna. Även Arnlaug Leira (1992) tar upp välfärdsstatens janusansikte. Hon menar att den skandinaviska välfärdsstaten visserligen bidragit till att förbättra kvinnors ställning, men att den samtidigt ger fördelar åt det som är typiskt för mäns vardagspraktiker och tidsanvändning. Det 
sker framförallt via ett mycket grundläggande drag i välfärdsstatens struktur;

Velferdsstaten har vidarefort en sentral forutsetning i den industrielle kapitalisme, et skille mellom det markedsorganiserte arbeidet og andre former for arbied (Leira 1992s 22).

Många forskare som ägnat sig åt att studera välfärdsstaten, både de som har ett feministiskt perspektiv och andra, har alltså kommit fram till att den svenska och den engelska välfärdsstaten har och har haft i grunden olika ideal och inriktning. Men med ovanstående som bakgrund finns det dessutom skäl att hävda att klassifikationer kan ha kort livslängd, bli mycket olika beroende på vilket område inom ett lands socialpolitik som studeras och hur det görs. Det finns därför också många outforskade områden av jämförande socialpolitik. Kanske det är så att specifika undersökningar just på delområden inom socialpolitiken kan ge nytt och spännande bränsle till diskussionen.

\section{Metod och urval}

För att jämföra hur vård och omsorg om förskolebarn är organiserat i Sverige och England har jag dels valt att närmare studera tillgången på barnomsorg $\mathrm{i}$ två områden och dels vilka arbetsmarknads- och socialförsäkringsbestämmelser som gäller i samband med ett barns födelse och tiden närmast efter. Jag har inte jämfört de särskilda bestämmelser som gäller för handikappade barn eller barn till ensamstående föräldrar.

Barnomsorg, utbildning och socialtjänstens individ- och familjeomsorg är i England uppgifter som "landstingen" har hand om, inte som i Sverige kommunerna. Jag har därför valt att göra jämförelsen mellan ett engelskt "landsting" (county) och ett befolkningsmässigt ungefär lika stort område i Sverige.

Det empiriska underlaget för jämförelsen av barnomsorgen består av en enkätundersökning bland 38 mellansvenska kommuner. Samtliga kommuner i Örebro-, Värmlands- och Västmanlands län (TUS-län) fick 1992 och 1993 besvara en enkät om barnomsorgen. För två av kommunerna redovisas en sammanvägning av svaren från olika kommundelar. Enkäten skickades till ansvarig chef för kommunens barnomsorg. Resultatet av den svenska enkäten jämförs med uppgifter om barnomsorgen i Leicestershire från hösten 1992. Uppgifterna är hämtade ur en rapport från Leicestershire County Council och täcker den service som ges till barn under åtta år av socialförvaltningen, skolan, privata och frivilliga sektorn, sjukvården och District Councils.

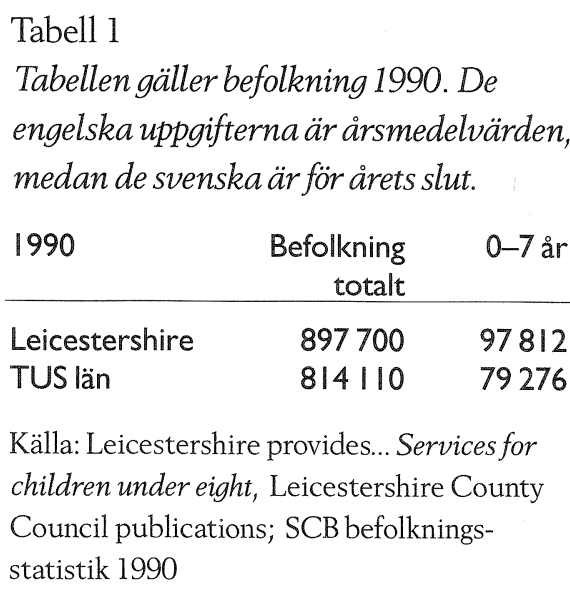

Det svenska och det engelska området är på flera sätt lika även om det förstås också finns stora skillnader. Bl.a. bor det ca 18500 
fler barn under åtta år i det engelska "landstinget« än vad det gör sammanlagt i de tre svenska länen. Det engelska området är geografiskt betydligt mindre och har därför en befolkningstäthet som är fjorton gånger högre. Andelen invandrare är i båda områdena ungefär lika. Nio procent av befolkning i Leicestershire och åtta i det svenska området är födda utomlands. Andelen ensamstående föräldrar som bor själva med minst ett barn i ålder under sexton år är också ungefär lika. Fjorton procent i TUS-län och tretton i Leicestershire ${ }^{1}$. Något färre engelska män än svenska arbetar. Arbetslösheten i de engelska området var också några procent högre än i det svenska ${ }^{2}$ både bland män och kvinnor. Den största skillnaden gäller dock kvinnornas sysselsättning. Bland kvinnor mellan sexton och femtionio år arbetar i TUS-län åttiotvå procent medan bara sextiosex procent av kvinnorna i Leicestershire $^{3}$ har ett jobb utanför hemmet.

\section{Förskolebarn}

Med begreppet förskolebarn menas barn som ännu inte börjat den obligatoriska grundskolan. Tidigare handlade det i Sverige om noll till sjuåringar. Men nu börjar allt

1 Uppgifter från nov 1990 för Sverige och april 1991 för England. Källor: SCB, FOB, 1990 ; HMSO Census 1991.

2 Leicestershire 7,9 procent för män och 4,2 procent för kvinnor. TUS-län 2,5-4,5 procent för män och 2,1-3,7 procent för kvinnor. Källor: SCB, AKU 1991 och HMSO, Census 1991.

3 Uppgifter från nov 1990 för Sverige och april 1991 för England. Källor: SCB, FOB 1990 ; HMSO, Census 1991. fler sexåringar i skolan och förskolebarn är alltså barn i åldern noll till sex eller sju år.

I England börjar barnen i den obligatoriska skolan vid fem års ålder. Men det blir också allt vanligare att skolorna har sk »4+ units» där man tar emot barn redan från fyra års ålder. 20 procent av "primary schools» i Leicestershire har "4+ units». Förskolebarn i England är alltså barn i åldern noll till fyra eller fem år.

De engelska barnen börjar skolan två år tidigare än de svenska barnen. Det betyder också att det sannolikt finns något färre förskolebarn i Leicestershire jämfört med i det svenska området TUS-län.

\section{Barnomsorgsdebatt}

Debatten om barnomsorgens roll i de flesta länder har två olika utgångspunkter, dels "Vad gör verksamheten för barnen?", dels "Vilken roll spelar barnomsorgen för ökande resp minskande kvinnligt deltagande på arbetsmarknaden? (Kamerman 1991).

Både i Sverige och i England har det under det senaste året pågått en intensiv debatt om barnomsorgen. I England har debatten handlat om behovet av en ekonomiskt överkomlig barnomsorg. Det kan sägas vara kopplat till den sistnämnda frågan. I Sverige har debatten till stor del handlat om införande av vårdnadsbidrag eller ej. Även det rör frågan om kvinnors förvärvsarbete. Drivande inom det familjepolitiska området i Sverige har framförallt KDS, Kristdemokratiska samhällspartiet varit. Den borgerliga regeringen införde i juli 1994 ett vårdnadsbidrag för barn upp till tre år. Ett ur socialpolitisk synpunkt märkligt bidrag som hittills bara funnits Finland. Ett bidrag för- 
äldrar får för att inte ha sina barn i den kommunala barnomsorgen.

Ett vårdnadsbidrag av den här typen är omöjligt att tänka sig att de engelska politikerna skulle införa. Det finns trcts allt skillnad på konservatism i svensk tappning och konservatism i engelsk tappning. Under partikongressen hösten 1993 stärkte högern sin ställning inom torypartiet i England. John Major manade i sitt avslutningstal sina partikollegor till en återgång till traditionella värden:

Det är dags att människor accepterar att ta ansvar för sig själva och för sin familj och inte skyfflar över det på staten (Nerikes Allehanda 93-10-08.).

Även om Majors uttalande inte specifikt rör barnomsorgen är det ändå ett uttryck för det synsätt som finns starkt förankrat i engelsk politik - att vård och omsorg hör hemma i den privata sfären och inte är något som staten skall lägga sig i. Även i Sverige hör vård och omsorg framförallt hemma i den privata sfären men statens roll är helt annorlunda. Här griper staten in i vård och omsorgsfrågor på ett mycket påtagligt sätt. Det visar bl.a. beslutet om att införa vårdnadsbidrag och barnomsorgsgaranti.

\section{Föräldrarna och staten}

En jämförelse av de arbetsmarknads- och socialförsäkringsbestämmelser som gäller i samband med ett barns födelse och tiden närmast efter visar stora skillnader.

\section{Sverige}

Moderskaps- och föräldrapenning

Vid barns sjukdom
Någon av föräldrarna har rätt att vara hemma med barnet med ekonomisk ersättning under 15 månader (64 veckor) med 90 procent av lönen under 12 mån och $60 \mathrm{skr} / \mathrm{dag}$ under resterande tre månader. Dessutom finns möjlighet att få Havandeskapspenning före förlossningen under högst 50 dagar för den blivande mamma som har ett fysiskt ansträngande arbete. Från I januari 1995 införs en »pappamånad« samtidigt sänks ersättningen till 80 procent av lönen förutom under två månader då den fortfarande blir 90 procent.

Om barnet är sjukt eller om ordinarie vårdare är sjuk m.m. 60 dagar per barn och år +

\section{England}

Ersättning från Statutory Maternity Pay (SMP) eller Maternity Allowance (MA) ges under max 18 veckor. SMP med 90 procent av lönen i sex veckor eller ca $600 \mathrm{skr}$. MA med ca 550 skr/vecka. Dessutom betalas ett engångsbelopp på ca 1250 skr ut till mammor med dålig ekonomi att användas till utrustning till babyn.

saknas. 
ytterligare 60 dagar per barn och år som gäller enbart vid barns sjukdom med 90 procent av lönen. Kan fr.o.m. Jan 95 även överlåtas från föräldrarna till annan person.

Kontaktdagar

Rätt till barnomsorg

Vårdnadsbidrag

Barnbidrag
2 dgr per barn och år för barn mellan 4 och 12 år. Kan användas bl.a. för att besöka barnet på daghem, förskola eller fritidshem.

Sedan 1985 finns en uttalad målsättning att kunna ge alla barn som så önskar en plats inom barnomsorgen. Fr.o.m Jan 1995 införs en barnomsorgsgaranti.

Sedan juli 1994. 2000 skr per månad till de som inte utnyttjar kommunal barnomsorg.

För alla barn. Högre belopp per barn vid mer än tre barn. saknas.

Barnomsorg en privat angelägenhet utom för de barn som lever under sociala missförhållanden, eller är handikappade.

Inga liknande planer förekommer.

För alla barn. Lägre belopp per barn fr.o.m. andra barnet jämfört med första barnet.
I Sverige kan alltså någon av föräldrarna vara hemma med sitt barn med betald ledighet under 64 veckor. I England kan mamman vara hemma med betald ledighet under 18 veckor. I det engelska systemet är pappan helt osynlig dvs. han finns där enbart som familjeförsörjare inte alls som vårdare. I det svenska systemet har pappan möjlighet att ta del av vården och omsorgen om sitt barn. Även om det fortfarande är kvinnan som bär huvudansvaret i familjen för vård och omsorg så tycks också i Sverige en aktivare papparoll vara på väg. Men det går långsamt. Andelen svenska pappor som var pappalediga någon gång under barnets första 18 månader har ökat från 27\% 1981 till drygt 45 procent 1990. Av de pappor som fick barn 1990 tog 27 procent ut minst 30 föräldrapenningdagar. 12 procent av papporna var lediga minst tre månader. (RFV Redovisar: 1994:1)

I Sverige har staten gjort det möjligt för någon av föräldrarna att under relativt lång tid vara hemma med sitt nyfödda barn för att sedan arbeta deltid. Genom lagstiftningen har föräldrarnas rätt att komma tillbaka till arbetet på en likvärdig nivå också skyddats. Se tabell 2 på nästa sida.

De svenska kvinnorna förvärvsarbetar i högre utsträckning än de engelska kvinnorna ${ }^{4}$. Fler svenska kvinnor än engelska är

4 Christina Jonung och Inga Persson (Jonung m.fl. 1993) har i en artikel pekat på svårigheterna med internationella jämförelser av förvärvsarbetsfrekvenser. 
Tabell 2

Rätt till ledighet i samband med barns födelse.

Förvärvsarbete (1992).

\section{Sverige}

Tills barnet är 18 månader. Dessutom har föräldrarna rätt till nedsatt tjänstgöring till 75 procent av heltid tills barnet fyllt 8 år.

\section{8 procent av kvinnorna med} minderåriga barn.

\section{England}

14-29 veckor.

65 procent av kvinnorna med minderåriga barn. ekonomiskt aktiva. Skillnaderna blir än mer påtagliga om man jämför småbarnsmammornas situation. Däremot för männen är förhållandet relativt likartat i de båda länderna.

Av de engelska kvinnor vars yngsta barn var ett förskolebarn i ålder 0-4 år förvärvsarbetade 199242 procent (General Household Survey 1992).

Av svenska kvinnor med yngsta barnet i förskoleåldern ${ }^{5}$ 0-6 år förvärvsarbetade 199281 procent (SCB-AKU 1992).

Det är alltså stora skillnader mellan länderna när det gäller hur mycket kvinnor med förskolebarn förvärvsarbetar, framförallt när det gäller heltidsarbete. Nästan dubbelt så många svenska mammor med förskolebarn förvärvsarbetar jämfört med de engelska. Nu har de svenska mammorna också lite större barn vilket kan göra det lättare att arbeta än för de engelska mammaorna där enbart 0-4-åringar betraktas som förskolebarn. En jämförelse av förvärvsarbete bland kvinnor med minderåriga barn dvs barn under 17 år visar att det fortfarande finns stora skillnader men inte lika

5 De engelska barnen börjar skolan vid 4-5 års ålder medan de svenska barnen börjar skolan först vid 6-7 års ålder. stora som för de mammor som har de minsta barnen.

Tabell 3 överst på sid 169 visar i procent hur utvecklingen varit när det gäller förvärvsarbete för kvinnor ${ }^{6}$ med minderåriga barn. $^{7}$

Nästan tre gånger så många engelska kvinnor med minderåriga barn som svenska är hemma och förvärvsarbetar inte alls. Dubbelt så många engelska kvinnor med minderåriga barn är också arbetslösa. En annan tydlig skillnad mellan kvinnorna i de båda länderna är att dubbelt så många svenska kvinnor som engelska heltidsarbetar trots att de har minderåriga barn. Däremot är det inte några större skillnader mellan länderna när det gäller deltidsarbete för kvinnor med minderåriga barn.

Sammanfattningsvis kan man säga att hemmafruarna tycks alltså vara mycket vanligare i England än i Sverige medan de heltidsarbetande småbarnsmammorna i sin tur är mycket vanligare i Sverige än i England.

Enkäten i det svenska området visade att för föräldrarna i hälften av kommunerna i

6 16-59 år i England och 16-64 år i Sverige

7 För England barn under 16 år eller mellan 1618 år om barnet heltidsstuderar och hör till familjen. För Sverige barn under 17 år. 


\section{Tabell 3}

$\begin{array}{lrrrrc} & 1987^{8} & 1989 & 1990 & 1991 & 1992 \\ \begin{array}{l}\text { larbetskraften } \\ \text { Sverige }\end{array} & 89 & 90 & 90 & 89 & 88 \\ \text { Storbritannien } & 60 & 63 & 63 & 65 & 65 \\ \begin{array}{l}\text { Heltid } \\ \text { Sverige }\end{array} & 38 & 43 & 44 & 44 & 43 \\ \text { Storbritannien } & 18 & 20 & 21 & 22 & 20 \\ \begin{array}{l}\text { Deltid } \\ \text { Sverige }\end{array} & 48 & 46 & 45 & 43 & 41 \\ \text { Storbritanien } & 37 & 39 & 39 & 36 & 39 \\ \begin{array}{l}\text { Arbetslös } \\ \text { Sverige }\end{array} & 2 & 1 & 1 & 2 & 3 \\ \text { Storbritannien } & 5 & 4 & 3 & 6 & 6 \\ \begin{array}{l}\text { Ej i arbetskraften } \\ \text { Sverige }\end{array} & 11 & 10 & 10 & 11 & 12 \\ \text { Storbritannien } & 40 & 37 & 37 & 36 & 35 \\ & & & & & \\ \text { Källor: SCB, AKU- undersökningarna 87-92; HMSO, General Household Survey } 1992\end{array}$

TUS-län var det möjligt att själva dela omsorgen om barnet under de första 15 månaderna för att sedan direkt få en plats på ett daghem antingen $i$ kommunal eller alternativ regi.

Den 17 december 1993 beslöt den svenska regeringen att fro.m. 1 juli 1994 införa vårdnadsbidrag för de föräldrar som vill minska sin arbetstid eller vara hemma på heltid. 2000 skr per månad kan utgå för barn mellan ett och tre år. Familjer som utnyttjar kommunal barnomsorg mer än 30 timmar per vecka får inte vårdnadsbidrag. Samtidigt beslöt riksdagen att kommunerna skall vara skyldiga att från 1 januari 1995 ge barnomsorg till de som efterfrågar det för barn mellan ett och tolv år. För att främja

8 Jämförbara siffror saknas för 1988 från England valfrihet och mångfald blir kommunerna också skyldiga att stödja enskilt drivna förskolor och fritidshem. I England förekommer varken något liknande barnomsorgsgaranti eller vårdnadsbidrag.

De svenska kvinnorna har alltså betydligt större möjlighet än de engelska kvinnorna att få en lugn start tillsammans med sitt barn samtidigt som de kan behålla sitt arbete för att under flera år arbeta deltid med samma arbete som tidigare. Vård och omsorg av barnen är även i Sverige i huvudsak kvinnornas ansvar. Bara i ca var tionde familj tar också de svenska männen ett ansvar för de riktigt små barnen genom att utnyttja föräldrapenning i mer än tre månader (RFV 1994:1). De engelska männen förutsätts lönearbeta, inte ta hand om små barn. 


\section{Tillgång på barnomsorg för förskolebarn}

Men det är inte bara möjligheterna till vård och omsorg i familjen som är intressanta utan också hur skärningspunkten mellan det offentliga och den privata sfären ser ut. För att närmare granska och jämföra den barnomsorg som förekommer på lokal nivå inom befolkningsmässigt ungefär lika stora områden i de två länderna har jag gjort en indelning av barnomsorgen i fyra kategorier.

1) heltidsbarnomsorg av grupper av barn dvs. daghem/nurseries

2) deltidsbarnomsorg ( $\max 4$ timmar/dag) av grupper av barn

3) av en person anställd av föräldrarna som tar hand om barnen i det egna hemmet dvs. barnflicka/nanny eller au pair.
4) i någon annans privata hem dvs. hos dagmamma/childminder

Huvudman för den offentliga barnomsorgen är i Sverige kommunerna och i England County councils, organisatoriskt närmast motsvarande våra landsting. I Sverige har socialförvaltningen $\mathrm{i}$ huvudsak ansvaret för barnomsorgen även om man i vissa kommuner under senare år bildat en särskild gemensam förvaltning för skola och barnomsorg. I England delar socialförvaltningen (Social Services Department) och skolförvaltningen (Local Education Authority) på ansvaret för den offentliga barnomsorgen. Parallellt med den offentliga barnomsorgen finns i båda länderna en mängd alternativ som drivs som privata företag, av frivilliga organisationer eller andra lokala grupper t.ex. föräldrar.

\section{Sverige}

Daghem/Nurseries

Deltidsverksamheter

Barnflicka/nanny/au pair

Dagmamma/childminder

Illegal barnomsorg

\begin{abstract}
Den offentliga barnomsorgen är till för alla barn. I ca hälften av kommunerna finns ingen kö till den offentliga barnomsorgen.

I I/3 av kommunerna står de alternativa daghemmen för ett betydande inslag, framför allt föräldrakooperativ och daghem drivna av olika intressegrupper.
\end{abstract}

stor variationsrikedom.

fåtal.

offentligt anställda dagmammor.

»svarta《 dagmammor i ca hälften av kommunerna.

\section{England}

Den offentliga barnomsorgen är främst till för barn med sociala problem.

Färre barn finns i enskilt drivna daghem i Leicestershire än i det svenska området.

stor variationsrikedom.

relativt vanligt.

privata dagmammor.

»svarta《 dagmammor förekommer i området. 


\section{Daghem/nurseries}

Heldagsbarnomsorgen har framförallt vuxit fram ur ett behov av tillsyn av förskolebarnen medan föräldrarna arbetar.

I Sverige beslöt riksdagen 1985 att alla barn som ville skulle få en plats i den kommunala barnomsorgen. 1993 fanns i nästan hälften av kommunerna inom TUS-län inga köer. Det är framförallt heltidsomsorg i kommunala daghem som kommit att dominera. Utvecklingen visar dock att det under perioden jan. 1992- mars 1993 skett en kraftig ökning av daghem som drivs av föräldrar eller olika intressegrupper. Det sker alltså en förskjutning i riktning mot den privata sfären, mot brukarhåll. Men utveck- lingen är inte likartad $i$ alla kommuner.

I det svenska området är de kommunala daghemmen till för alla barn som bor i ett område. I Leicestershire är de kommunala daghemmen i första hand till för barn som bedöms vara i riskzonen för misshandel, försumlighet eller övergrepp av olika slag samt barn med handikapp. Utvecklingen i Leicestershire är att de kommunala daghemmen minskar i antal.

Tabell 4 visar antalet kommunala daghem respektive daghem som drivs i alternativ regi. Det kan vara som privata företag, personalkooperativ, föräldrakooperativ eller av föreningar eller andra lokala grupper (Uppgifter från 92/93).

\section{Tabell 4

\begin{tabular}{|c|c|c|c|c|}
\hline & $\begin{array}{r}\text { Antal } \\
\text { kommunala } \\
\text { daghem }\end{array}$ & $\begin{array}{r}\text { Antal barn } \\
\text { i kommunala } \\
\text { daghem }\end{array}$ & $\begin{array}{r}\text { Antal } \\
\text { alternativa } \\
\text { daghem }\end{array}$ & $\begin{array}{r}\text { Antal barn } \\
\text { i alternativa } \\
\text { daghem }\end{array}$ \\
\hline $\begin{array}{l}\text { Leicestershire } \\
\text { TUS-län }\end{array}$ & $\begin{array}{c}15 \\
\text { ca } 694 * * *\end{array}$ & $\begin{array}{c}710 \\
23943 *\end{array}$ & $\begin{array}{c}56 \\
\operatorname{ca} 99 * *\end{array}$ & $\begin{array}{c}1379 \\
\mathrm{ca}|88| \text { ** }\end{array}$ \\
\hline
\end{tabular}

Heldagsbarnomsorgen för förskolebarn är betydligt mer utbyggd i Sverige än i England. Det gäller både i offentlig regi och i alternativ regi dvs som privata företag, personal eller föräldrakooperativ, föreningsdrivna eller daghem drivna av lokala grupper.

Den största skillnaden gäller daghem i offentlig regi. Ett engelskt kommunalt daghem motsvaras av 46 svenska. Varje engelsk barn med plats på kommunalt daghem motsvaras av 34 svenska barn. Det finns dessutom nästan dubbelt så många daghem i al- ternativ regi i det svenska området jämfört med i det engelska. Så trots att den offentliga barnomsorgen är kraftigt utbyggd i Sverige finns det ändå en minst lika stor andel heltidsbarnomsorg med annan huvudman än stat och kommun som i det engelska området.

\section{Deltidsverksamheter}

Deltidsverksamheternas inriktning är inte i första hand att ta hand om barnen medan föräldrarna arbetar vilket väl kan sägas om daghemmen/dagmammorna/barnflickorna 
även om de också erbjuder stimulans åt barnen. Deltidsverksamheternas primära inriktning är däremot oftast att ge barnen stimulans.

Att göra någon rättvisande jämförelse när det gäller antalet barn som deltar i olika deltidsgrupper i de båda länderna låter sig inte göras. Variationsrikedomen är stor och flera av verksamhetstyperna har inte något regelbundet närvarokrav.

\section{Barnflicka/nanny/au pair}

Vad som också skiljer Sverige från England är att möjligheterna att anställa någon som hjälp med att sköta hushållsarbete och barnen i hemmet. I realiteten har möjligheten inte funnits i Sverige under 70-, 80- och 90talet. Det blev för dyrt och betraktades dessutom som överklassfasoner och inte något som var acceptabelt i den växande medelklassen. Men under senaste året har en s.k. "pigdebatt" på nytt blossat upp sedan borgliga politiker börjat argumentera för att man på olika sätt skall underlätta för dem som vill anställa någon som hjälp i hemmet. I England däremot är det relativt vanligt med nanny/au pair.

\section{Dagmamma/childminder}

I båda länderna finns system med dagmammor som i sitt eget hem tar hand om andras barn för hela dagen eller delar av den. Men systemen är olika utformade.

I Sverige är dagmamman som regel anställd av kommunen. Barnet får sin plats hos dagmamman genom kommunens kösystem och det är till kommunen föräldrarna betalar sina avgifter. Arbetsplatsen är däremot, precis som i England, dagmammans privata hem. I England betraktas förhållandet mellan dagmamman och föräldrarna som privat. Kommunen har inga dagmammor anställda och är inte heller inblandad när det gäller avgifter annat än för de barn som p.g.a. särskilda behov placerats hos dagmamma av socialförvaltningen. Social services department registrerar, övervakar och inspekterar däremot dagmammorna i området.

Tabell 5 nederst på sidan visar antalet dagmammor och antalet barn hos dagmammorna 1992.

En jämförelse på lokal nivå visar att det finns ungefär lika många dagmammor i lika stora områden. Däremot är det ca tre gånger så många barn hos varje dagmamma i Sverige jämfört med Leicestershire.

En påtaglig skillnad mellan det svenska och det engelska systemet är att de svenska dagmammorna är anställda av kommunerna. De svenska dagmammorna är professionella dagmammor och det krävs att de

\begin{tabular}{lrrr} 
Tabell 5 & $\begin{array}{r}\text { Antal } \\
\text { dagmammor }\end{array}$ & $\begin{array}{r}\text { Antal barn } \\
\text { hos dagmamma }\end{array}$ & $\begin{array}{r}\text { Antal barn/ } \\
\text { dagmamma }\end{array}$ \\
\cline { 2 - 4 } & 2588 & 5024 & 1.9 \\
Leicestershire & 2586 & 16457 & 6.4
\end{tabular}

Källor: Kommunala jämförelsetal 1993:3 Jämförelsetal för socialtjänsten 1992. Leicestershire provides.... (1993) 
har barnen hos sig ganska många timmar per vecka för att få heltidslön. I England ligger dagmammeyrket närmre den privata sfären och arbetet kvinnor traditionellt alltid utfört med vård och omsorg av barn $i$ hemmet. Leicestershire Childminding Association skriver så här:

Childminders are not sprofessionalsı but usually a mum at home. It is difficult then to conform to standards of day care services as seen by the professional, aspects of childminding are lost by things like inspecting kitchens etc. as in a professional setting. (Leicestershire provides... 1993: 7:12).

Skillnaden i professionaliseringsgrad kan sannolikt till viss del förklara skillnaderna i antalet barn som dagmammorna i Sverige respektive England har hand om.

\section{Svart barnomsorg}

Vid sidan av det offentliga systemet tycks det också finnas en svart barnomsorgsmarknad i båda länderna.

ISverige har det under lång tid funnits en svart marknad för barnomsorg. Enkäten visade att det i nästan hälften av kommunerna (47,5 procent) fortfarande fanns "svarta dagmammor" enligt barnomsorgspersonalens uppfattning. I England har inte informationen om de nya kraven på registrering av de som vill arbeta som dagmammor helt trängt igenom. Bl.a. därför finns det "svarta dagmammor» även där. Men även de krav som myndigheterna ställer kan vara ett hinder för registrering.

\section{Avslutande diskussion}

Barnomsorgen i Sverige och England fungerar efter skilda socialpolitiska principer. I
Sverige har den offentliga barnomsorgen en generell inrikting. Den gäller för alla barn och ska också finnas tillgänglig för alla barn som behöver en plats. I England riktar sig den offentliga barnomsorgen framförallt till barn med sociala problem eller handikapp. Marknadsorienterade lösningar som t.ex. privata dagmammor blir ett komplement till de system som har sin bas i familj och nätverk. I England går utvecklingen mot en ökad samhällelig kontroll av den barnomsorg som ges av enskilda. Den engelska staten ser alltså omsorgsfrågorna som ett i huvudsak privat problem och ingriper bara när barnen riskerar att skadas, fara mycket illa eller behöver särskilt stöd. I Sverige däremot uppfattas omsorgen av de små barnen som både ett privat och ett offentligt ansvarsområde. Den svenska staten/kommunerna ger både ekonomiskt och praktiskt ett omfattande stöd till familjerna. Den svenska staten kan med Antonnens begrepp beskrivas som en omsorgsstat medan den engelska mer är att betrakta som en kontrollstat. Men basen för vård och omsorg om de små barnen är i båda länderna familj och nätverk.

I England är till skillnad från omsorgsfrågorna utbildning betraktat som ett offentligt ansvarsområde. Statens stöd till familjerna tar där istället formen av allt tidigare utbildning för barnen.

Barnomsorgen i de båda länderna fungerar efter skilda socialpolitiska principer. I det svenska området har den offentliga barnomsorgen en generell inrikting. I Leicestershire riktar sig den offentliga barnomsorgen framförallt till en viss grupp barn, de utsatta barnen, barn med sociala problem eller andra handikapp.

En annan tydlig skillnad mellan situatio- 
nen i Sverige och England är synen på pappans roll när det gäller vård och omsorg om förskolebarnen. I England är det bara mamman som har rätt att vara hemma med det nya barnet. I Sverige har inte bara mamman utan också pappan rätt till föräldrapenning och att stanna hemma för att vårda sjukt barn. Det finns i England en tydlig markering att vård och omsorg är och skall vara ett privat problem och ett kvinnligt ansvarsområde. I Sverige däremot tycks en aktivare papparoll långsamt vara på väg.

Att de skilda systemen får olika konsekvenser för kvinnorna blir tydligt när man jämför kvinnornas förvärvsfrekvens. Betydligt fler svenska kvinnor med små barn än engelska arbetar. Lewis beskriver England som en stark "malebreadwinnerustat och Sverige som en »dualbreadwinnerıstat. Den här jämförelsen visar att England också kan beskrivas som en "femalecarerıstat - en kvinnovårdarstat och Sverige som en "dualcarerustat - en tvåpartsvårdarstat, men där den andra vårdande parten förutom kvin- norna är staten. Pappan tar visserligen i Sverige ett allt större ansvar för vård och omsorg om de små barnen, men det lär ändå dröja länge innan ansvaret delas av tre parter. Att män och kvinnor tar lika stort ansvar för omsorgen om de små barnen och att de i det ansvarstagandet har stöd från staten eller i vidare mening samhället - ett samhälle där alla har ett gemensamt ansvar för barnen. I den svenska välfärdsstatens arrangemang finns ett tydligt stöd för att kvinnor också som småbarnsmammor kan vara förvärvsarbetare. Det saknas i det engelska systemet. Men att de svenska kvinnorna har en gynsammare situation än de engelska, beror till stor del på att det i den svenska välfärdsstaten skett en förskjutning från det privata till det offentliga och att kvinnors lönearbete accepterats snarare än att det skett en radikal förändring av patriarkatet. När nu utvecklingen vänder och den privata sfären åter får en ökad betydelse blir det tydligt att också de svenska kvinnorna befinner sig i en mycket sårbar situation. 


\section{Referenser}

Anttonen, Anneli(1990) "The feminization of the Scandinavian Welfare State", i Simonen, L.,(red) Finnish debates on Woman Studies, Tampere: University of Tampere Research Institute for Social Science

Borchorst, Anette (1992) "Europaeisk integration, konsarbejdsdeling og ligestillingspolitik", Eneroth, B. \& Michaeli,I. red.; Kvinnornas välfärdsstat? Nordiska kvinnoforskare diskuterar. Gävle: Statens institut för byggnadsforskning.

Bradshaw, J., Ditch, J., Hillary, H. \& Whiteford, P., (1993) A comparative study of child support in fifteen countries, Journal of European Social Policy, 3:4, 255-271

Brunnberg, Elinor (1992) Barnomsorgen $i$ ÖrebroVärmland- och Västmanlands län. Örebro: Högskolan i Örebro opublicerat paper

Employment department, Pressnotice 1 july 1993, David Hunt promises early implementation as act receives royal assent. London: Employment department

Equal Opportunities Commission (1993) Formal response of the equal opportunities comission to trade union reform and employment right bill. London : Equal Opportunities Commission, 107, jan 93.

Esping - Andersen, Gosta (1990) The three worlds of welfare capitalism, Cambridge: Polity Press

HMSO, 1991 Census County Report: Leicestershire(Part 1)

HMSO, General Household Survey 1992

Jonung, Christina \& Persson, Inga, (1993): Notes and issues Women and Market Work: the misleading Tale of Participation Rates in International Comparisions. Work, Employment \& Society, 7: 2, 259-274
Kamerman,Sheila (1991): Child care Policies and Programs: An international Overview. Journal of Social Issues, 47:2,179-196

Kommunala jämförelsetal 1993:3 Jämförelsetal för socialtjänsten 1992 Stockholm/Örebro:

Socialstyrelsen, Svenska kommunförbundet, $\mathrm{SCB}$

Leicestershire provides...Services for children under eight in Leicestershire. (1993) Leicestershire: A Leicestershire County Council publication

Leira, Arnlaug, (1992) "Velferdsstat og hverdagsliv", Eneroth, B.\&Michaeli, I. red.: Kvinnornas välfärdsstat? Nordiska kvinnoforskare diskuterar. Gävle: Statens institut för byggnadsforskning.

Lewis, Jane, (1992) „Gender and the development of welfare regimes", Journal of European Social Policy, 2:3, 159-173

Maternity Alliance (1993) Pregnant at work. London

Nerikes Allehanda931008 : „Sluta dalta med medborgarna« Högern framåt inom torypartiet.

RFV Redovisar: 1994:1, Från moderskap till föräldraskap

SCB Befolkningsstatistik 1990

SCB Arbetskraftsundersökning (AKU) 19871992

SCB Folk och bostadsräkning (FOB) 1990

Siim, Birte, (1990) „Feministiska tolkningar av samspelet mellan kvinnor och välfärdsstaten«. Kvinnovetenskaplig tidskrift, 2, 13-25

Statistiska meddelanden, S10SM 9301

White, Carr and Love,(1990) A guide to the children act 1989, London: Butterworths

Brunnberg - Vård och omsorg av förskolebarn i Sverige och England 


\section{Summary}

\section{Care of pre-school children in Sweden and England}

There are great differences between the welfare state in Sweden and in Great Britain in relation to parents with small children. This is very clear when the support for families with pre-school children are examined on a local level. The Swedish parents have much more support from the state than the English parents have during this period with a child. In England the care of pre-school children is a private problem, not a task for the state unless the parents have mismanaged the care of the child. The English state has a controlling role, not a caring one. In Sweden the state takes a very active part in the care of preschool children.

The English state can not only be characterized as a male breadwinner-state, as the English researcher Jane Lewis does, but also as a female carer-state, while Sweden is a dual breadwinner-state and a dual carer-state. The second caring party in Sweden is the state. In Sweden too it is the women who have the primary responsibility for the care of pre-schoolchildren even if a change in the role of the fathers is slowly appearing.

This article compares the current regulations when a new child is born and the access of child welfare. The empirical material is from a survey in 38 Swedish local authorities and an English County Council with almost the same number of people, Leicestershire.

On the local level there are great differences in the way the child welfare is organized. One public day nursery in Leicestershire corresponds to 46 public day nurseries in the Swedish area. Besides there are twice as many day nurseries privately run or managed by organizations or parents in the Swedish area than in the English. The public day nurseries in England are mainly for children with social or other problems. The public day nurseries in Sweden are for all children. There are almost the same number of childminders in Leicestershire and in the Swedish area, but each Swedish childminder takes care of three times as many children as in England. The Swedish childminders are employed by the local government, the English are private. 